\title{
Fluorescent Antibody Procedure
}

National Cancer Institute

\section{Source}

National Cancer Institute. Fluorescent Antibody Procedure. NCI Thesaurus. Code

C17370.

An immunological procedure in which the antibodies are coupled with molecules which

fluoresce under ultra violet (UV) light. This makes them particularly suitable for detection of specific antigens in tissues or on cells. 